\title{
鼻中隔に生じた神経鞘腫症例
}

\author{
八木 昌人・浅井 昌大 \\ 伊藤 健・山柤 達也
}

\section{A Case of Neurinoma of the Nasal Septum with Multiple Neurinomas}

\author{
Masato Yagi, Masao Asai, \\ Ken Itoh and Tatsuya Yamasoba \\ (University of Tokyo)
}

We report a case of neurinoma of the nasal septum with multiple spinal tumors. The patient was a 21-year-old female. She had undergone resection of multiple neurinomas of the spine at the age of 18 , and her father had also undergone resection of multiple spinal neurinomas and neurofibromas.

She visited our hospital because of right nasal obstruction and rhinorrhea of 2 years duration. Anterior rhinoscopy revealed a mass in her right nasal cavity. GT scanning showed a soft tissue density mass in the posterior part of the nasal cavity. Nasal cavity tumor was diagnosed and the tumor was resected through a transantral approach under general anesthesia. Operative findings revealed that the tumor developed from the nasal septum. Histopathological finding of the tumor was Antoni A and B type neurinoma.

Key words : neurinoma, nasal septum, multiple, neurilemmomatosis

\section{緒言}

鼻中隔腫瘍の報告は数多くみられ，その病理 組織像は多彩である。しかし，報告例の多くは 多形腺腫であり，神経鞘腫の報告は著者らの検 索しうる範囲では国内，国外を通じて 8 例を数 えるにすぎない，今回私どあは多発性神経鞘腫 の既往歴, 家族歷を持つ鼻中隔神経鞘腫の 1 症 例を経験したので報告し，自験例および過去の 報告例をむとに鼻中隔神経鞘腫の臨床像につい て若干の考察を加えたい.

\section{症例}

患者 : 22歳，女性

\section{主訴：右鼻閉，鼻漏}

既往歷: 1985年 2 月, 頸椎から腰椎にわたる 7 個の脊䯣神経鞘腫の摘出術をうけている.

家族歷: 父が春髄の多発性神経鞘腫, 神経線 維腫にて数回摘出術をうけている.

現病歷：1986年 5 月乙ろから右鼻閉，および 粘稠な鼻漏が出現していたが放置していた。し かし，症状は次第に増悪してきたため1988年 5 月28日当科を受診する.

全身所見: 背部正中の 3 力所に手術瘏痕が存 在し, 左側腹部に $2 \times 2.5 \mathrm{~cm}$, 右腰部に直径 $8 \mathrm{~mm}$ の色素沈着をみとめた. (なお，この 2 力 
所の色素沈着は von Recklinghausen 病の診断 基準には該当しない）また，頸部では左胸鎖乳 突筋後縁に直径 $5 \mathrm{~mm}$ の弾性硬で圧痛のある腫 瘤を触知した。

局所所見：前鼻鏡所見では右総鼻道から嗅裂 下部にかけて弾性硬で，表面はやや凹凸不整で 血管拡張のみられる黄褐色の腫瘤が存在し, 腫 瘤と鼻中隔㧍よび下甲介との間に消息子を挿入 してみたが瘾着の有無は明らかではなかった (図 $1 \mathrm{~A}$ ). また，後鼻鏡所見ではこの腫瘤は 右後鼻孔をこえて，上咽頭に突出していた（図 $1 \mathrm{~B})$.

CT 所見：軸位 CT では右鼻腔後部に soft tissue density を示す直径約 $30 \mathrm{~mm}$ の mass が存在し，その内部はやや low density を呈し ていた. また mass によって鼻中隔後部は内側 へ，右下甲介および上顎洞内側壁は外側へ圧排 されていたが，明かな骨欠損は存在しなかった (図 2).

経過：既往歴，家族歴より神経鞘腫が最む考 えられた。また，腫瘤の原発部位として鼻中隔 後部または下甲介後部が考えられたが，明らか な原発部位を特定できなかったため，鼻腔腫瘍 として1988年 7 月18日全身麻酔下に腫瘍摘出術 を施行した。

手術所見: 手術は美容上の問題も考慮し, 外

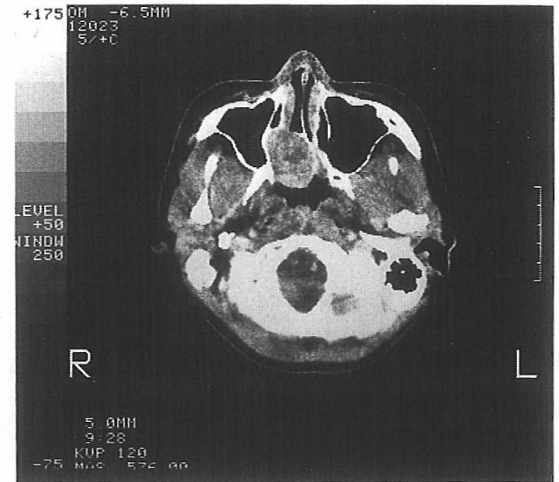

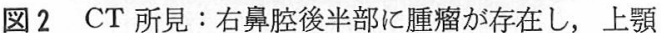
洞内側壁および鼻中隔を压排している。しか し，あきらかな骨破壊像は存在しない。

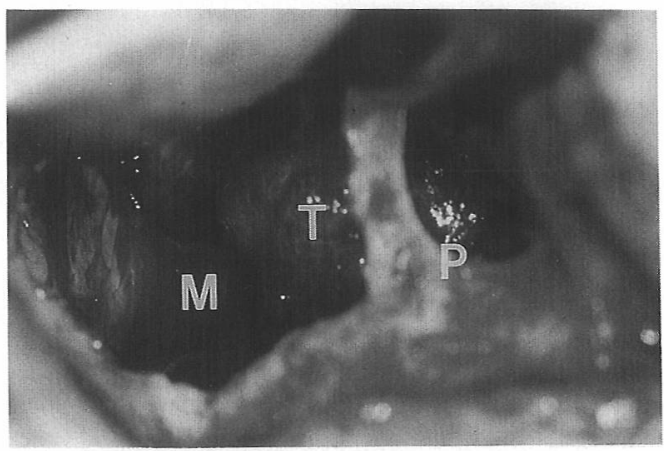

図 3 術中所見：梨状孔縁を保存しながら，経上顎洞 的に宜腔側壁をおとし腄瘤を直視下に扔いた。 腫瘤と鼻腔側壁との癒着はなく, 鼻中隔後半部 より広基性に発生しているのが確認された。

$\mathrm{M}$; 上枵洞 $\mathrm{P}$; 梨状孔縁 $\mathrm{T}$; 腫瘤
A

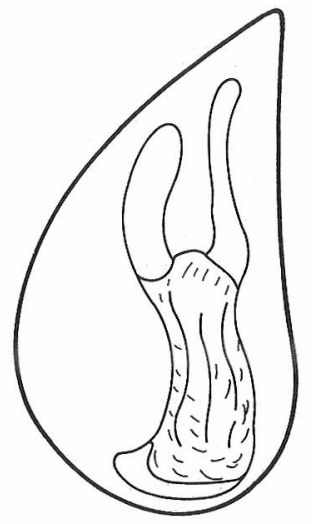

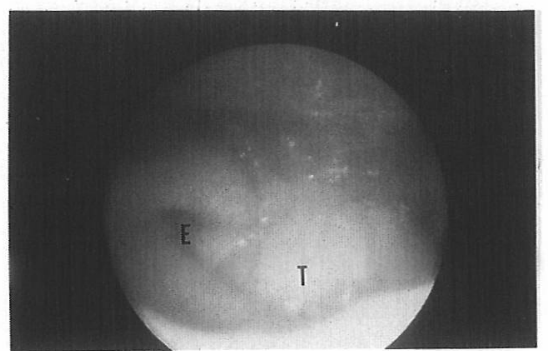

B

図1A 前鼻鏡所見：右総鼻道から嗅裂下部にかけて腫瘤をみとめる。

$\mathrm{B}$ 後鼻鏡所見：腫瘤は右後鼻孔をてえて上咽頭に突出している. $\mathrm{E} ;$ 耳管開口部

$\mathrm{T}$; 腫瘤 
切開ではなく，歯龉切開による経上顎洞アプロ 一チで抢とない，術後の頓部の陥凹を防ぐため 梨状孔縁を保存する方針とした。

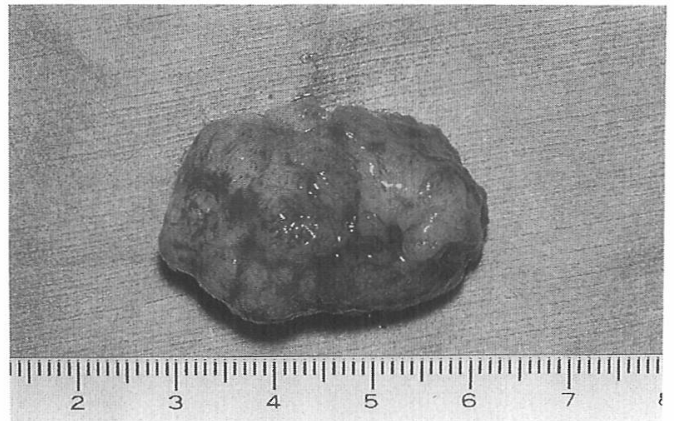

図 4 摘出標本

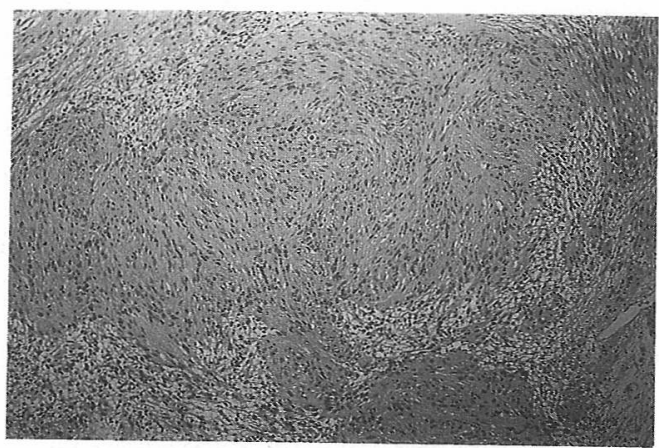

図 5 病理組織所見：腫瘍は，紡鍾形の細胞が palisading を形成する密な部分と myxoid な間質か らなる陳な部分からなりたっている。 Antoni A，B 混合型の神経鞘腫之診断された。
経上顎洞的に上顎洞内側壁および下甲介を摘 出したところ，腫瘍と下甲介との癒着はなく， 腫瘍は鼻中隔後部に原発するととが確認された (図 3 ). そこで，腫瘍前方の鼻中隔粘膜に切開 を入れ，鼻中隔軟骨膜下，骨膜下に㔀離を進 め，腫瘍を摘出した（図 4).

病理組織所見：腫瘍の実質は細胞配列の密な 部分と疎な部分からなり，密な部分は紡鍾形の 細胞が palisading を形成し,疎な部分は myxoid な間質の中に紡鍾形の細胞が散在する所見であ った (図 5). 以上加ら AntoniA，B 混合型の 神経鞘腫と晾断した。

なお，先に述べた左胸鎖乳突筋後縁の腫瘤は 昭和 63 年 8 月当院整形外科にて摘出された. その病理組織学的所見屯同様に神経鞘腫であ った。

術後経過は良好で1989年 1 月まで再発をみと めず鼻症状も改善している。また，聴神経腫瘍 の発生もみとめられていない.

考察

鼻中隔腫瘍は他の鼻副鼻腔領域のものに比し て稀なものとされている。しかし，その組織型. は多彩であり，病理組織学的に検討しうるほと んどすべての腫瘍がみられるといっても過言で はない.

ところで，鼻中隔腫瘍においては以前から多

表 1 鼻中隔神経鞘腫報告例

\begin{tabular}{|c|c|c|c|c|c|}
\hline 報告 者（年） & 年 齢 性 & 症 状 & 腫 瘍 の 性 状 & 治 療 法 & 組 織 所見 \\
\hline $\begin{array}{r}\text { Bogdasarian }^{1)} \\
(1943)\end{array}$ & $42, \mathrm{M}$ & 左鼻閉 & $\begin{array}{l}\text { 淡赤烑色卵形 } \\
\text { キーセルバッ部位に付着 }\end{array}$ & 寒蹄系で絞断 & Antoni A, B \\
\hline 市 原8（1956） & $63, \mathrm{~F}$ & 鼻 閉 & 鼻茸様 & 寒蹄系で絞断 & \\
\hline $\begin{array}{l}\text { Aznauryan }^{22} \\
\text { (1959) }\end{array}$ & $36, \mathrm{M}$ & 鼻 閉 & 血腫様 & & \\
\hline Fajstavr $^{3)}$ (1963) & & 鼻閉，鼻出血 & & & \\
\hline 松 崎4 & $34, \quad \mathrm{~F}$ & 左鼻閍, 鼻出血 & $\begin{array}{l}\text { 平滑, 淡赤灰色〜分葉状, 污穢茶褐色 } \\
\text { 鼻中隔後上部に茎 }\end{array}$ & $\begin{array}{l}\text { 和过一Denker } \\
\text { 氏法 }\end{array}$ & Antoni A, B \\
\hline Thomas $^{5)}$ (1977) & $21, \mathrm{~F}$ & 右鼻閉 & 平滑，硬 & 外側鼻切開 & Antoni A \\
\hline 結 束6) (1979) & $49, \quad F$ & & & & Antoni A \\
\hline 永 田 ${ }^{7}$ & $6, \mathrm{M}$ & 左鼻出血 & $\begin{array}{l}\text { 鼻色，硬 } \\
\text { 中隔部に存在 }\end{array}$ & 鼻内法 & Antoni A \\
\hline (1989) & $22, \quad \mathrm{~F}$ & 右鼻閉 & $\begin{array}{l}\text { 黄褐色, 凹凸不整, 弾性硬 } \\
\text { 畕中隔後部に存在 }\end{array}$ & $\begin{array}{l}\text { Caldwell-Luc } \\
\text { 法 }\end{array}$ & Antoni A, B \\
\hline
\end{tabular}


形腺腫の発生がよく知られており，現在までに 多数の報告がみられる。そそれに対し，神経鞘腫 の報告は現在までに国内，国外を通じ自験例を 含めてあわずか 9 例を数えるにすぎない(表 1 ). そのため，比較的稀とされる鼻中隔腫瘍の中で 屯神経鞘腫はとくに数少ないことが想像され る. そこで, 前述した 9 例を検討し, 鼻中隔神 経鞘腫の臨床像について考察を試みる.

先ず，表 1 に 9 例の詳細を示す。それによる と発症年㱓は 6 歳から63歳にわたり, 性別の判 明している例では, 男女比は $3 ： 5$ であった。 症状では鼻閉が最も多くみられ，乙の他には 9 例中 3 例に鼻出血のみられたととが注目され る. 本来神経鞘腫は易出血性の腫瘍ではないと いわれており, 鼻副鼻腔神経鞘腫においても, 林田らによる20例の文献的検討8) で，鼻出血は 鼻腔神経鞘腫 3 例, 鼻中隔神経鞘腫 1 例の計 4 例のみで，腫瘍が副鼻腔に限局している例には みられなかった，乙のととから，鼻出血は腫瘍 が鼻腔内において機械的刺激を受けることによ り生じてくる可能性が高いと考えられる.

腫瘍の性状は，鼻茸様のものから不規則分葉 状で血管怒張をみるものまで報告により様々で あり, 視触診上は神経鞘腫に特徵的な所見はみ られない。 また，画像診断においても特徴的な 所見は存在しないが，悪性腫瘍を思わせるよう な骨破壊像を示した例は見出されなかった。確 定診断は腫瘍の組織学的検索によるが，術前に 生検を施行し確定診断のついた症例はなく，い ずれも良性腫瘍の診断のもとに摘出術を施行 し，摘出標本から神経鞘腫と判明したものであ った。

鼻中隔に分布する神経は，前方は三叉神経の 第 1 枝の枝である前篩骨神経，後方は三叉神経 の第 2 枝の枝である鼻口蓋神経であり，後者は 知覚神経線維の他に自律神経線維 も含んでい $ろ^{9)}$. 神経鞘腫は末梢神経の Schwann 細胞由 来の腫瘍であるため, 当然のととに鼻中隔神経 鞘腫は前述の神経から発生するが，現在までに 明らかに起源神経を同定できた報告はない。し
かし，神経の走行から，腫瘍の発生部位によっ て起源神経の推定は可能である. そてで，過去 の報告例における鼻中隔腫瘍の発生部位につい て検討したところ，自験例を除く 8 例中発生部 位について言及した報告は 3 例みられた。この うち 2 例はキーセルバッ八付近，他の 1 例は鼻 中隔後半部からであった，したがって，先に述 べた神経の走行を考慮すると，前 2 者が前篩骨 神経，後者が鼻口蓋神経由来と考えられる．自 験例に関しても神経の同定はできなかったが， 腫瘍が鼻中隔後半部に位置していたてとから鼻 口蓋神経由来と考えるのが適当と思われた。

鼻中隔神経鞘腫の治療は手術による摘出が唯 一の方法であり，現在までの報告例はいずれむ 摘出術を施行している. 腫瘍へのアプローチと して文献的には，鼻内法，経上顎洞法，鼻外法 の 3 つが挙げられているが，それぞれに長所短 所が存在する。例えば，鼻外法は広い術野が得 られるが，術後顔面に手術瘢痕が残る欠点があ り，鼻内法，経上顎洞法は美容上の問題は少な いが術野が狭く手術操作に限界がある。自験例 の場合経上顎洞的に腫瘍を摘出したが，術後の 煩部の変形をさけるため，梨状孔縁を極力保存 する方針で行なった．術式の選択にあたっては 腫瘍の根治性を第一に考えることはいうまでむ ないが，神経鞘腫は良性腫瘍でああり，その根 治性とともに美容上の問題屯考慮するととが重 要である。

神経鞘腫は通常単発性であるが，ときに多発 することがある ${ }^{9)}$. この多発性神経鞘腫には同 一神経に多発するあの之，全身各所に多発する あのが存在し, 後者として von Recklinghausen 病（以下 $\mathrm{R}$ 病と略）打よび多発性神経鞘腫症 ${ }^{10}$ が知られている.自験例の場合現在までに脊䯣, 鼻中隔, 頸部皮下に神経鞘腫が発生しているこ とから前述のような全身疾患の存在が疑われ る.

R病はカフェオレスポットと多発性神経線維 腫が特徴であり，ときに多発性に神経鞘腫の発 生をみることもある。そそれに対し，多発性神経 
鞘腫症の場合, カフェオレスポットは存在せ ず，通常家族歷も存在しないといわれている ${ }^{10)}$. しかし，多発性神経鞘腫症を $\mathrm{R}$ 病の不全型とし て考える報告ああり ${ }^{11)}$ ，多発性神経鞘腫症を $\mathrm{R}$ 病とは別の疾患と定義するには議論の余地があ りそうである，ところで，自験例の場合，カフ エオレスポットや神経線維腫は存在していない が，父に多発性神経線維腫の発生をみているた め将来神経線維腫が発生してくる可能性を否定 できない，そのため，現在の状態からは全身性 に神経鞘腫の多発をきたす疾患の存在は確定的 といえるが， R 病か多発性神経鞘腫症かの鑑別 は困難であるといわざるをえない.

全身的に神経鞘腫の発生をみる疾患のばあ い，皮膚に神経鞘腫の多発をみることが多く， そのほかには聴神経, 春髄等での発生が知られ ている ${ }^{10)}$ が，鼻中隔はもとより鼻副鼻腔領域に 神経鞘腫に発生をみたという報告はない。つま り，神経鞘腫が多発する際屯好発部位といわれ る部分に出現しやすい傾向があるようである. また，現在までに報告された鼻中隔神経鞘腫の 症例をみてあ，乙れらはいずれも単発性であ り, 身体の他の部位に神経鞘腫の発生した症例 はみいだされなかった．以上の検討から，多発 性神経鞘腫の 1 症状として鼻中隔神経鞘腫が出 現した症例は著者らの検索しうる範囲では自験 例が最初の報告例と考えられる。

\section{結語}

1. 多発性神経鞘腫の 1 症状としてみられた 鼻中隔神経鞘腫の 1 例を報告した.

2. 現在までに鼻中隔神経鞘腫は国内，国外 で自験例を含め 9 例報告されているにすぎな い. このうち自験例を除く 8 例はいずれも単発 性であった。

3. 多発性神経鞘腫症について文献的考察を おこなった。それによると，鼻副鼻腔領域に神 経鞘腫が発生した症例は見出されなかった。
4. 多発性神経䩗腫症の 1 症状として鼻中隔 に神経鞘腫が発生した例は検索しえた範囲内で は存在せず，自験例は初の症例之考えられる。

\section{参考文献}

1) Bogdasarian RM and Stout AP : Neurilemmoma of the nasal septum. Arch Otolaryngol 38 : 62 64, 1943.

2 ) Aznauryan KS : Neurinoma of the nasal septum. Zbl. Hals usw Heilk $66:$ 140, 1960.

3) Fajstavr $\mathrm{J}:$ Neurinoma of the nasal septum. Zbl Hals usw Heilk 79 : 131, 1963 64.

4 ）松崎 力, 設楽哲也 : 鼻中隔より発生した神経鞘 腫の 1 例. 耳喉 $39: 615 \sim 620,1967$.

5 ) Thomas JN : Massive schwannoma arising from the nasal septum. J Laryngol Otol $91: 63 \sim 68$, 1977.

6 ）結束 温, 武宮之三, 嶋田文之：鼻中隔 neurinoma について一電顕的観察— “On a fine structure of the neurinoma occurred from the nasal septum." 日鼻副会誌 $16: 116 \sim 117,1979$.

7 ) 永田和人, 粕谷尚男, 古賀淳子: 鼻中隔より発生 した神経鞘腫の 1 例. 小倉記念病院紀要 $17: 25$ 26, 1984 .

8 ）林田邦彦, 山田篤伸, 南立昌幸, 他：鼻腔に発生し た神経鞘腫の 2 症例. 耳鼻 $19: 626 \sim 632,1973$.

9 ）宇山 正, 木村 秀, 三浦一真, 他 : 肋間神経に 多発した神経鞘腫の 1 例と本邦報告例の集計.日 胸外会誌 $35: 107 \sim 111,1987$.

10) Shishiba T, Niimura M, Ohtsuka F,et al:Multiple cutaneous neurilemmomas as a skin manifestation of neurilemmomatosis. J Am Acad Dermatol $10: 744 \sim 754,1984$.

11）池田重雄, 川村太郎：von Recklinghausen 母玟 症. 症候群1982. 228～229頁，日本臨牀，大阪， 1982.

原稿採択 : 平成元年 2 月 22 日 別刷請求先 : 八木昌人 T113 東京都文京区本郷7-3-1 東京大学医学部耳鼻咽喉科学教室) 